\section{Salinity Tolerance of Seashore Paspalum Ecotypes: Shoot Growth Responses and Criteria}

\author{
Geungjoo Lee ${ }^{1}$ \\ Center for Applied Genetic Technologies, 111 Riverbend Road, Athens, \\ GA 30602
}

\author{
Ronny R. Duncan ${ }^{2}$ and Robert N. Carrow ${ }^{3}$ \\ Department of Crop and Soil Sciences, University of Georgia, Griffin, \\ GA 30223-1797
}

Additional index words. turfgrass, electrical conductivity, solution/sand culture, Paspalum vaginatum, Cynodon dactylon $\mathrm{x}$ C. transvalensis

\begin{abstract}
Evaluation of turfgrass salt tolerance is a basic strategy for selecting grasses that can be grown in areas with salt-affected water or soils. Our objectives were to determine the relative salinity tolerances of 32 grasses and to evaluate potential shoot-based criteria for assessing salinity tolerance. Shoot growth responses to salinity of $\mathbf{2 8}$ seashore paspalums (Paspalum vaginatum Swartz) and four bermudagrass [Cynodon dactylon $(\mathrm{L}$. $x$ C. transvalensis Burtt-Davy] cultivars were investigated under solution/sand culture in a greenhouse. Turfgrasses were grown in a sea-salt amended nutrient solution. Salinity ranges were 1.1 to $41.1 \mathrm{dS} \cdot \mathrm{m}^{-1}$ based on electrical conductivity of the solution $\left(\mathrm{EC}_{\mathrm{w}}\right)$. Selection criteria to assess salt tolerance were absolute growth at $1.1\left(\mathrm{EC}_{w} 0\right), 24.8\left(\mathrm{EC}_{\mathrm{w}} 24\right)$, $33.1\left(\mathrm{EC}_{\mathrm{w}} 32\right)$, and $41.1 \mathrm{dS} \cdot \mathrm{m}^{-1}\left(\mathrm{EC}_{\mathrm{w}} 40\right)$; threshold $\mathrm{EC}_{\mathrm{w}} ; \mathrm{EC}_{\mathrm{w}}$ for $25 \%$ and $50 \%$ growth reduction based on $\mathrm{EC}_{\mathrm{w}} \mathrm{O}$ growth; and leaf firing (LF) at $\mathrm{EC}_{\mathrm{w}} \mathrm{O}$ and $\mathrm{EC}_{\mathrm{w}} 40$ ( $\mathrm{LF0}$ and LF40, respectively). Significant variations among 32 entries were observed for all shoot responses except threshold $\mathrm{EC}_{\mathrm{w}}$. Ranges of values for shoot parameters were: inherent growth at $\mathrm{EC}_{\mathrm{w}} \mathrm{O}=0.10$ to $0.98 \mathrm{~g}$ dry weight $\left(10\right.$-fold difference); growth at $24.8 \mathrm{dS} \cdot \mathrm{m}^{-1}=$ 0.11 to $0.64 \mathrm{~g}$; growth at $33.1 \mathrm{dS} \cdot \mathrm{m}^{-1}=0.09$ to $0.54 \mathrm{~g}$; growth at $41.4 \mathrm{dS} \cdot \mathrm{m}^{-1}=0.06$ to 0.35 $\mathrm{g}$; threshold $\mathrm{EC}_{\mathrm{w}}=3.9$ to $12.3 \mathrm{dS} \cdot \mathrm{m}^{-1} ; \mathrm{EC}_{\mathrm{w}} 25 \%=14$ to $38 \mathrm{dS} \cdot \mathrm{m}^{-1} ; \mathrm{EC}_{\mathrm{w}} 50 \%=22$ to 43 $\mathrm{dS} \cdot \mathrm{m}^{-1}$; and $\mathrm{LF40}=7 \%$ to $41 \%$. Results in this study indicated substantial genetic-based variation in salt tolerance within seashore paspalums. When evaluation of salt tolerance based on shoot responses is attempted at wide salinity levels up to $40 \mathrm{dS} \cdot \mathrm{m}^{-1}$, all seven criteria exhibiting a significant $F$ test can be used. Five entries (SI 92, SI 93-1, SI 91, SI 93-2, SI 89) were ranked in the top statistical grouping for all seven-growth parameters, followed by SI 90 ranked in six out of seven, and three paspalums (SI 94-1, 'Sea Isle 1', and 'Taliaferro') were ranked in five out of seven categories.
\end{abstract}

Salt-affected soils impact nearly $10 \%$ of the land surface $\left(\approx 9.5 \times 10^{8}\right.$ ha) and $50 \%$ of all irrigated land $\left(\approx 2.3 \times 10^{8} \mathrm{ha}\right)$ in the world (Carrow and Duncan, 1998; Epstein et al., 1980; Rengasmy and Olsson, 1991). Increased use of brackish water and salt-laden wastewater (effluent, recycled, or reclaimed water) has enhanced interest in development of more salt-tolerant turfgrasses (Carrow and Duncan, 1998; Marcum et al., 1998).

Seashore paspalum exhibits tolerances to various abiotic stresses, including extreme acidic and alkaline soil $\mathrm{pH}$, drought, and wear (Duncan and Carrow, 1999; Huang et al., 1997; Trenholm et al., 1999; Wilkinson and Duncan, 1994). The turfgrass has demonstrated superior salt tolerance compared to other turfgrasses (Dudeck and Peacock,

Received for publication 26Aug. 2002. Accepted for publication 16 May 2003. This paper is a portion of a thesis submitted by G.J. Lee. Funding from the U.S. Golf Association and Georgia Turfgrass Foundation Trust is gratefully acknowledged.

${ }^{1}$ Postdoctoral associate.

${ }^{2}$ Professor; to whom reprint requests should be addressed.

${ }^{3}$ Professor
1985; Lee, 2000; Marcum and Murdoch, 1994; Morton, 1973). Ecotypes of seashore paspalum grow on coastal sites subjected to seawater $\left(34,486 \mathrm{mg} \cdot \mathrm{L}^{-1}\right.$ total soluble salts or electrical conductivity of $\mathrm{EC}_{\mathrm{w}}$ of $54 \mathrm{dS} \cdot \mathrm{m}^{-1}$ ) (Duncan, 1996a, 1999b). The initial cultivar of seashore paspalum for turfgrass sites in the United States, however, was 'Adalayd', a cultivar introduced from Australia that has salt tolerance comparable to some bermudagrass cultivars and quality traits similar to coarsetextured common bermudagrass (Duncan, 1999a; Liu et al., 1994).

Plant species and cultivars within a species vary in their salinity tolerance (Epstein et al., 1980; Pasternak, 1987; Saranga et al., 1992). These salt tolerance variations probably result from the expression of a number of genes (between 100 and 1000) relating to different salinity tolerance mechanisms and their interaction with environments, since numerous salt tolerance mechanisms have been reported for plants (Bohnert et al., 1995; Duncan and Carrow, 1999; Igartua, 1995; Shannon, 1985). Evaluations for salt tolerance of plants have traditionally been based on shoot (aboveground) growth, as reported in crop yield response curves proposed by Maas and Hoffman (Igartua, 1995; Maas, 1987; Maas and Hoffman, 1977). They plotted relative growth or yield (i.e., vegetative growth, fruit or seed production, grain yield, fiber production, storage-root yield) vs. increasing salinity. Relative yield was based on percentage of yield at a particular $\mathrm{EC}_{\mathrm{e}}$ (electrical conductivity of a saturated soil paste extract) compared to yield at control as the $100 \%$ base. One of the important criteria for evaluating salinity tolerance was threshold $\mathrm{EC}_{\mathrm{e}}$, the soil salinity at which relative yield started to decline compared to the control $\left(\mathrm{EC}_{\mathrm{e}}=0 \mathrm{dS} \cdot \mathrm{m}^{-1}\right)$. A second factor to consider was the slope of the growth curve vs. $\mathrm{EC}_{\mathrm{e}}$ line in the $\mathrm{EC}_{\mathrm{e}}$ range where growth started to decline, where a small decline in growth per unit increase in salinity level would indicate some level of tolerance.

While these salinity tolerance criteria are useful for many crops, the necessity for development of different criteria was proposed by Carrow and Duncan (1998) for halophytic (salt-tolerant) perennial turfgrasses. First, they noted that absolute growth was a more meaningful criterion than relative growth rates for turfgrasses subjected to salinity stresses. A grass with a high inherent (absolute) shoot growth rate is important for wear tolerance of grasses under salinity stress, since a major effect of salt stress is to inhibit water uptake, induce drought stress and, therefore, limit growth (i.e., diminishing recoverability from wear stress or injury). Use of relative growth may allow a grass to be classified as salt tolerant when, in fact, it could not sustain adequate growth to persist under salinity stress and high traffic conditions. Use of absolute growth as one selection criterion would also screen salinity tolerance and provide growth comparisons as affected by level of salinity. Turfgrasses used in salt-affected sites but not subjected to traffic may persist with a lower inherent growth rate.

Second, Carrow and Duncan (1998) indicated that halophytic turfgrasses (salt-tolerant plants persisting at $\mathrm{EC}_{\mathrm{e}}>30 \mathrm{dS} \cdot \mathrm{m}^{-1}$ ) exhibit growth curves that differ from those proposed by Maas and Hoffman (1977). Prior research on plant salinity tolerance assessment has focused primarily on glycophytes (salt-sensitive plants), which represent most agronomic and horticultural plants (Maas, 1987; Maas and Hoffman, 1977) at the salinity ranges $<30 \mathrm{dS} \cdot \mathrm{m}^{-1}$. Salinity responses of halophytes typically include growth increase as salinity increases, followed by a reduction in growth at higher salinity. However, the growth reduction may not be consistent or uniform, thereby not allowing for a glycophytic response in which a linear slope factor can be determined.

Third, much higher salinity levels $\left(\mathrm{EC}_{\mathrm{e}}>30\right.$ $\mathrm{dS} \cdot \mathrm{m}^{-1}$ ) are required for assessing salt tolerance of halophytes such as a seashore paspalum (Lee, 2000). Above this salinity, most agronomic or horticulture crops do not survive, so that differences in salt tolerance based on growth curves were not considered at high salinity $>30 \mathrm{dS} \cdot \mathrm{m}^{-1}$ in Maas and Hoffman's approach (1977). In fact, any crop with a threshold $\mathrm{EC}_{\mathrm{e}}$ $>10 \mathrm{dS} \cdot \mathrm{m}^{-1}$ is classified as very salt tolerant and no further division above the salinity level 
was classified. For true halophytes, growth responses in the salinity range $>30 \mathrm{dS} \cdot \mathrm{m}^{-1}$ would be necessary for determining salinity tolerance. Likewise, grasses that survive between $\mathrm{EC}_{\mathrm{e}}=30$ to $54 \mathrm{dS} \cdot \mathrm{m}^{-1}$ (seawater) need to be classified into other classes rather than simply as very tolerant.

Fourth, Carrow and Duncan (1998) noted that, generally, shoot data have been used for assessing salt tolerance in the traditional evaluation for most crops, but additional growth criteria (roots, verdure, leaf firing) and physiological criteria (osmotic adjustment, salt gland density, compatible solutes) are required for perennial turfgrasses for determining salinity tolerance, as has been reported earlier(Dudeck and Peacock, 1985; Lee et al., 1994; Marcum, 1999; Marcum et al., 1998; Qian et al., 2000).

The objectives in this study were to 1) evaluate the range of salinity tolerance within seashore paspalum ecotypes compared to selected bermudagrasses based on shoot growth performance, and 2) determine which shoot growth parameters provided the best differentiation of grasses for salinity tolerance classification over the $\mathrm{EC}_{\mathrm{w}}=0$ to $41 \mathrm{dS} \cdot \mathrm{m}^{-1}$ range.

\section{Materials and Methods}

Growing conditions and treatments. This experiment was conducted using sea-salt solution/sand culture in a greenhouse at the Georgia Agricultural Experiment Station, Griffin, during April through Oct. 1997. A total of 2.5-cmdiameter plugs of 28 seashore paspalums and four hybrid bermudagrass cultivars ('Tifgreen', 'Tifway', 'Tifsport', 'Tifeagle') were initially transplanted into trays containing a mixture of sand and peat. Routine irrigation and mowing practices (mowing at $2.5 \mathrm{~cm}$ ) were applied to establish the grasses uniformly for 2 months under greenhouse conditions. Uniform plugs were retransplanted on 8 June 1997 to coneshaped plastic pots (slightly smaller diameter at the bottom) filled with coarse sand $\left(11.4-\mathrm{cm}^{2}\right.$ top and 20-cm depth); plants were controlled with the same salt treatment. Pots were held in a plywood frame suspended over plastic containers containing $28 \mathrm{~L}$ of a modified, halfstrength Hoaglands No. 2 solution formulated with tap water (Hoagland and Arnon, 1950). Plastic pots were submerged to the soil surface in the solutions. Fe-EDTA chelate (Sprint 138, $6 \% \mathrm{Fe}$; Becker-Underwood, Ames, Iowa) at 2 $\mathrm{mg} \cdot \mathrm{L}^{-1}$ was supplied to the solution. To avoid algae growth, all exposed solution surface was covered with pieces of Styrofoam. Nutrient solution was aerated constantly, changed weekly, and maintained at a constant volume.

Treatments were imposed on 1 Aug. 1997 after plants were uniformly established in the pots. The sea-salt mixture was formulated based on salt composition (Peacock and Dudeck, 1985), and added at 0, 19.72, 27.02, and $34.32 \mathrm{~g} \cdot \mathrm{L}^{-1}$ to the nutrient solution to eventually give four salinity levels, which were measured using electrical conductivity of the solution $\left(\mathrm{EC}_{\mathrm{w}}\right)$ at $25{ }^{\circ} \mathrm{C}$ with an Orion conductivity meter (model 160; Boston). Originally salt treatments were aimed as control (nutrient only), $\mathrm{EC}_{\mathrm{w}} 24, \mathrm{EC}_{\mathrm{w}} 32$, and
$\mathrm{EC}_{\mathrm{w}} 40$, but $\mathrm{EC}_{\mathrm{w}}$ levels (average \pm standard deviation) measured during the experiment were $1.1 \pm 0.1,24.8 \pm 1.3,33.1 \pm 1.8,41.4 \pm$ $1.5 \mathrm{dS} \cdot \mathrm{m}^{-1}$, respectively. To avoid salt shock, $\mathrm{EC}_{\mathrm{w}}$ levels were gradually increased by the addition of $7.3 \mathrm{~g} \cdot \mathrm{L}^{-1}$ of sea salt mixture every day until each final salinity level was achieved (Peacock and Dudeck, 1985). Since sand in the pots was submerged in the salt solution, soil salinity $\left(\mathrm{EC}_{\mathrm{e}}\right)$ was considered to be equal to solution salinity $\left(\mathrm{EC}_{\mathrm{w}}\right)$.

Evaluation of salinity tolerance. After final salinity levels were attained on 6 Aug. 1997, shoots were mowed to a $2.5-\mathrm{cm}$ height over the soil surface and discarded, as were additional clippings discarded the following week. Thereafter, shoot clippings were collected from the cone-shaped pots $\left(11.4 \mathrm{~cm}^{2}\right)$ three times at 2 -week intervals to determine shoot growth. The clippings were immediately dried at $70^{\circ} \mathrm{C}$ for $48 \mathrm{~h}$ for dry weight (DW) measurement. The three harvests were combined to determine total shoot growth differences. Leaf firing (LF), based on percentage of leaves exhibiting visual symptoms of chlorosis or tissue desiccation, were rated on control and the $41.4 \mathrm{dS} \cdot \mathrm{m}^{-1}$ plots (LF0 and LF40, respectively) during the midpoint and at the end of the experiment.

Along with LF, the following shoot growth parameters or criteria were used as a function of salinity level: growth $\mathrm{EC}_{\mathrm{w}} 0$, growth $\mathrm{EC}_{\mathrm{w}} 24$, growth $\mathrm{EC}_{\mathrm{w}} 32$, growth $\mathrm{EC}_{\mathrm{w}} 40$ (total shoot growth at control, 24.8, 33.1, $41.4 \mathrm{dS} \cdot \mathrm{m}^{-1}$, respectively); threshold $\mathrm{EC}_{\mathrm{w}}$ (the salinity level associated with maximum shoot growth after which growth declines and at which maximum growth occurs) $\mathrm{EC}_{\mathrm{w}} 25 \%$ or $\mathrm{EC}_{\mathrm{w}} 50 \%$ (salinity level for $25 \%$ or $50 \%$ growth reduction from growth at control); and (salinity level indicating 50\% growth reduction with the $\mathrm{EC}_{\mathrm{w}} 0$ growth baseline). Growth vs. salinity level curves (Fig.1) were plotted for each grass to determine threshold $\mathrm{EC}_{\mathrm{w}}, \mathrm{EC}_{\mathrm{w}} 25 \%$, and $\mathrm{EC}_{\mathrm{w}} 50 \%$ data.

Experimental design and data analysis. Each container had 32 different grasses subjected to one salinity level, representing one treatment replication. Experimental design was a randomized complete block with six replications in a split plot arrangement, with salinity as the main plot and grass entry as the subplot (Peacock and Dudeck, 1985). All data were statistically analyzed with analysis of variance, using least significant difference (LSD) to separate the means among entries, with emphasis on identifying the entries in the top (best) statistical category for the significant measurements based on $F$-test (SAS Institute, 1988). Therefore, all grasses that were found to be statistically similar to the best entry within a column were considered in the top group (Trenholm et al., 1999). Pearson correlation coefficients were used to determine relationships between variables.

\section{Results}

Inherent growth (growth at $E C_{w} O$ or control). Inherent shoot growth at $\mathrm{EC}_{\mathrm{w}} 0$ was significantly different among entries (Table 1) and the range was from 0.10 to $0.98 \mathrm{~g} \mathrm{DW}$ collected over 2 months, which represented a 10 -fold difference among grasses. SI 92 was used as a standard for highest growth at $\mathrm{EC}_{\mathrm{w}} 0$ (control) to compare ecotypes, since SI 94-1 exhibited an unusually high growth among the paspalums. Based on the SI 92 standard, 11 seashore paspalums were in the top statistical group with $\mathrm{EC}_{\mathrm{w}} 0$ growth $\geq 0.60$. Among the bermudagrass cultivars, 'Tifgreen' had the highest inherent growth $(0.20 \mathrm{~g})$, which was similar to 'Adalayd'.

Growth at $E C_{w} 24$ and $E C_{w} 32$. Growth at $\mathrm{EC}_{\mathrm{w}} 24$ and $\mathrm{EC}_{\mathrm{w}} 32$ were significantly affected by salinity treatment, and differences between ecotypes were found (Table 1). Absolute shoot growth for seashore paspalum ecotypes at $\mathrm{EC}_{\mathrm{w}} 24$ ranged from 0.11 to $0.64 \mathrm{~g}$. Nine seashore paspalums were in the highest statistical growth category $\geq 0.51 \mathrm{~g}$ DW. All bermudagrass cultivars had shoot growth $\leq 0.23 \mathrm{~g}$, with 'Tifway' having the highest.

The range for shoot growth for seashore paspalums at $\mathrm{EC}_{\mathrm{w}} 32$ was 0.09 to $0.54 \mathrm{~g}$, with 11 ecotypes in the top statistical group with growth $\geq 0.42 \mathrm{~g}$ (Table 1). 'Tifgreen' showed the highest growth (0.25 g DW) among bermudagrasses, which was significantly better than 'Adalayd' $(0.10 \mathrm{~g})$, 'Tifeagle', and 'Tifsport'.

Increased growth from low to moderately high salinity is typical of halophytes (Greenway and Munns, 1980). Looking at growth trends between the control and $\mathrm{EC}_{\mathrm{w}} 24$, eight seashore paspalum ecotypes exhibited higher shoot growth at $\mathrm{EC}_{\mathrm{w}} 24$ than $\mathrm{EC}_{\mathrm{w}} 0$. All ecotypes showing higher shoot growth at $\mathrm{EC}_{\mathrm{w}} 24$ than at $\mathrm{EC}_{\mathrm{w}} 0$ had shoot weight less than $0.48 \mathrm{~g}_{\text {at }} \mathrm{EC}_{\mathrm{w}} 0$. Three bermudagrass cultivars ('Tifgreen', 'Tifway', 'Tifeagle') also exhibited higher absolute growth at $\mathrm{EC}_{\mathrm{w}} 24$ than $\mathrm{EC}_{\mathrm{w}} 0$.

'Salam' was the one cultivar exhibiting the highest percent increase in absolute growth from the control to $\mathrm{EC}_{\mathrm{w}} 24$ (17\%). Among bermudagrass cultivars, both 'Tifway' $(0.11$ to $0.23 \mathrm{~g}, 109 \%$ increase $)$ and 'Tifeagle' ( 0.10 to $0.19 \mathrm{~g}, 90 \%$ increase) showed substantial enhanced growth at $\mathrm{EC}_{\mathrm{w}} 24$ relative to $\mathrm{EC}_{\mathrm{w}} 0$.

As salinity increased from $\mathrm{EC}_{\mathrm{w}} 24$ to $\mathrm{EC}_{\mathrm{w}} 32$, enhanced shoot growth was noted in four seashore paspalums (SI90, SI96, 'Excalibur', and 'Fidalayel'). SI 90, among the highest ranking group in the top inherent growth at $\mathrm{EC}_{w} 0$, had a $16 \%$ increase in shoot growth from $\mathrm{EC}_{\mathrm{w}} 24$ to $\mathrm{EC}_{\mathrm{w}}$ 32. 'Tifgreen' exhibited $19 \%$ greater shoot growth at $\mathrm{EC}_{\mathrm{w}} 32$ than $\mathrm{EC}_{\mathrm{w}} 24$, while 'Tifway' (43\% decrease) and 'Tifeagle' (42\% decrease) had substantial loss in DW.

Growth at $E C_{w} 40$. Shoot growth for seashore paspalums at $\mathrm{EC}_{\mathrm{w}} 40$ ranged from 0.06 to $0.35 \mathrm{~g}$. Six seashore paspalums were within the top statistical group at 0.27 to $0.35 \mathrm{~g}$ and five (SI 94-1, SI 92, SI 93-1, SI 93-2, and SI 90) were among those exhibiting the highest inherent growth at $\mathrm{EC}_{\mathrm{w}} 0$. These grasses maintained 33\% (SI 94-1) to 58\% (SI 90) shoot growth at $\mathrm{EC}_{\mathrm{w}} 40$ compared to $\mathrm{EC}_{\mathrm{w}} 0$ growth. Growth for bermudagrasses was 0.06 to 0.13 g, which was comparable to 'Adalayd' (0.08 g). No significant difference was found among bermudagrasses.

Threshold $E C_{w}$. Threshold $\mathrm{EC}_{\mathrm{w}}$ values 
Table 1. Shoot growth characteristics of 30 entries responding to increasing salinity levels.

\begin{tabular}{|c|c|c|c|c|c|c|c|c|c|c|}
\hline \multirow[b]{2}{*}{ Entry } & \multicolumn{4}{|c|}{ Growth $\left(\mathrm{g} \cdot 11.4 \mathrm{~cm}^{-2}\right)^{\mathrm{z}}$} & \multirow{2}{*}{$\begin{array}{c}\text { Threshold } \mathrm{EC}_{\mathrm{w}}{ }^{\mathrm{y}} \\
\left(\mathrm{dS} \cdot \mathrm{m}^{-1}\right)\end{array}$} & \multirow{2}{*}{$\begin{array}{l}\mathrm{EC}_{\mathrm{w}} 25 \% \\
\left(\mathrm{dS} \cdot \mathrm{m}^{-1}\right)\end{array}$} & \multirow{2}{*}{$\begin{array}{l}\mathrm{EC}_{\mathrm{w}} 50 \% \\
\left(\mathrm{dS} \cdot \mathrm{m}^{-1}\right)\end{array}$} & \multicolumn{2}{|c|}{ Leaf firing $(\%)$} & \multirow{2}{*}{$\begin{array}{c}\text { Times in top } \\
\text { group }(7=\text { best })\end{array}$} \\
\hline & $\mathrm{EC}_{\mathrm{w}} 0$ & $\mathrm{EC}_{\mathrm{w}} 24$ & $\mathrm{EC}_{\mathrm{w}} 32$ & $\mathrm{EC}_{\mathrm{w}} 40$ & & & & $\mathrm{EC}_{\mathrm{w}} \mathrm{O}$ & $\mathrm{EC}_{\mathrm{w}} 40$ & \\
\hline SI 94-1 & $0.98 \dagger^{w}$ & $0.64 \dagger$ & $0.53 \dagger$ & $0.32 \dagger$ & $4.5(1.07)$ & 19 & 30 & 3 & $8 \dagger$ & 5 \\
\hline SI 92 & $0.81 \dagger$ & $0.60 \dagger$ & $0.54 \dagger$ & $0.28 \dagger$ & $5.0(0.99)$ & $30 \dagger$ & $36 \dagger$ & 3 & $9 \dagger$ & 7 \\
\hline SI 93-1 & $0.71 \dagger$ & $0.56 \dagger$ & $0.48 \dagger$ & $0.30 \dagger$ & $8.9(0.90)$ & $33 \dagger$ & $38 \dagger$ & 2 & $9 \dagger$ & 7 \\
\hline Sea Isle 1 & $0.70 \dagger$ & 0.45 & $0.42 \dagger$ & 0.22 & $10.5(0.80)$ & $27 \dagger$ & $34 \dagger$ & 3 & $9 \dagger$ & 5 \\
\hline PI 28960 & $0.67 \dagger$ & 0.49 & 0.35 & 0.23 & $8.8(0.92)$ & $29 \dagger$ & 33 & 2 & $8 \dagger$ & 3 \\
\hline SI 94-2 & $0.65 \dagger$ & $0.51 \dagger$ & $0.42 \dagger$ & 0.21 & $6.5(0.92)$ & 24 & 31 & 2 & $10 \dagger$ & 4 \\
\hline SI 91 & $0.64 \dagger$ & $0.55 \dagger$ & $0.42 \dagger$ & 0.25 & $9.0(0.81)$ & $29 \dagger$ & $36 \dagger$ & 2 & $10 \dagger$ & 7 \\
\hline SI 93-2 & $0.61 \dagger$ & $0.53 \dagger$ & $0.48 \dagger$ & $0.30 \dagger$ & $8.5(0.77)$ & $30 \dagger$ & $39 \dagger$ & 2 & $8 \dagger$ & 7 \\
\hline Sea Isle 2000 & $0.61 \dagger$ & 0.42 & 0.39 & 0.26 & $6.4(0.83)$ & 21 & $34 \dagger$ & 3 & $8 \dagger$ & 4 \\
\hline SI 90 & $0.60 \dagger$ & 0.38 & $0.44 \dagger$ & $0.35 \dagger$ & $11.9(0.93)$ & $31 \dagger$ & $43 \dagger$ & 2 & $7 \dagger$ & 6 \\
\hline SI 89 & $0.60 \dagger$ & $0.52 \dagger$ & $0.44 \dagger$ & 0.25 & $10.8(0.88)$ & $28 \dagger$ & $36 \dagger$ & 3 & $10 \dagger$ & 7 \\
\hline Temple 2 & 0.55 & 0.36 & 0.22 & 0.16 & $6.2(0.69)$ & 20 & 30 & 2 & $11 \dagger$ & 1 \\
\hline FSP 1 & 0.55 & 0.41 & 0.33 & 0.20 & $4.5(0.59)$ & 23 & 32 & 3 & $9 \dagger$ & 1 \\
\hline SI 96 & 0.48 & 0.39 & $0.47 \dagger$ & 0.22 & $7.8(0.56)$ & 19 & $39 \dagger$ & 3 & $9 \dagger$ & 3 \\
\hline SI 97 & 0.48 & 0.44 & 0.28 & 0.19 & $7.4(0.75)$ & 17 & $34 \dagger$ & 3 & $12 \dagger$ & 2 \\
\hline Taliaferro & 0.48 & $0.51 \dagger$ & 0.34 & $0.27 \dagger$ & $6.0(0.59)$ & $31 \dagger$ & $41 \dagger$ & 3 & $9 \dagger$ & 5 \\
\hline Salam & 0.46 & $0.54 \dagger$ & 0.29 & 0.21 & $12.3(0.77)$ & $29 \dagger$ & $38 \dagger$ & 2 & $11 \dagger$ & 4 \\
\hline SI 90-1 & 0.42 & 0.48 & $0.45 \dagger$ & 0.23 & $11.1(0.73)$ & $31 \dagger$ & $41 \dagger$ & 2 & $9 \dagger$ & 4 \\
\hline Hyb 5 & 0.37 & 0.31 & 0.26 & 0.21 & $10.3(0.44)$ & $26 \dagger$ & $41 \dagger$ & 3 & $11 \dagger$ & 3 \\
\hline Excalibur & 0.36 & 0.20 & 0.22 & 0.10 & $6.4(0.44)$ & 20 & $35 \dagger$ & 4 & 30 & 1 \\
\hline SI 90-3 & 0.33 & 0.38 & 0.34 & 0.18 & $11.0(0.53)$ & $38 \dagger$ & $41 \dagger$ & 3 & $10 \dagger$ & 3 \\
\hline SI 95 & 0.29 & 0.23 & 0.18 & 0.15 & $10.0(0.51)$ & $25 \dagger$ & 29 & 3 & 15 & 1 \\
\hline SI 90-2 & 0.27 & 0.28 & 0.22 & 0.19 & $8.9(0.53)$ & $33 \dagger$ & $38 \dagger$ & 2 & $9 \dagger$ & 3 \\
\hline Adalayd & 0.24 & 0.11 & 0.10 & 0.08 & $3.9(0.26)$ & 14 & 22 & 5 & 25 & 0 \\
\hline PI 509020 & 0.20 & 0.28 & 0.21 & 0.13 & $8.6(0.35)$ & $33 \dagger$ & $40 \dagger$ & 3 & 16 & 2 \\
\hline Tifgreen & 0.20 & 0.21 & 0.25 & 0.13 & $6.1(0.33)$ & $26 \dagger$ & $38 \dagger$ & 3 & 33 & 2 \\
\hline Fidalayel & 0.16 & 0.12 & 0.14 & 0.07 & $5.0(0.18)$ & $31 \dagger$ & $36 \dagger$ & 4 & 29 & 2 \\
\hline PI 509022 & 0.13 & 0.15 & 0.14 & 0.10 & $12.0(0.19)$ & $32 \dagger$ & $42 \dagger$ & 5 & 22 & 2 \\
\hline Tifsport & 0.12 & 0.11 & 0.09 & 0.06 & 7.9 (0.19) & 22 & $37 \dagger$ & 4 & 39 & 1 \\
\hline PI 509021 & 0.12 & 0.13 & 0.12 & 0.08 & $7.1(0.16)$ & $25 \dagger$ & $39 \dagger$ & 5 & 18 & 2 \\
\hline Tifway & 0.11 & 0.23 & 0.13 & 0.09 & $6.9(0.23)$ & $36 \dagger$ & $42 \dagger$ & 5 & 36 & 2 \\
\hline Tifeagle & 0.10 & 0.19 & 0.11 & 0.06 & $11.6(0.39)$ & $36 \dagger$ & $41 \dagger$ & 3 & 41 & 2 \\
\hline $\operatorname{LSD}_{(0.05)}$ & 0.25 & 0.14 & 0.12 & 0.08 & 7.1 & 13.3 & 10.0 & 5 & 7.0 & --- \\
\hline$F$-test & $* * *$ & $* * *$ & $* * *$ & $* * *$ & NS & $* * *$ & $* * *$ & NS & $* * *$ & --- \\
\hline $\mathrm{CV}(\%)$ & 56 & 38 & 42 & 40 & 79 & 41 & 24 & 3 & 34 & --- \\
\hline
\end{tabular}

${ }^{\mathrm{z}}$ Growth at control, 24.8, 33.1, and $41.4 \mathrm{dS} \cdot \mathrm{m}^{-1}$, respectively.

'Values in parentheses represent the absolute shoot growth ( $\mathrm{g}$ DW collected over $\left.11.4 \mathrm{~cm}^{2}\right)$ at the threshold salinity.

${ }^{x}$ Denotes the numbers of times the grass ranked in the top (best) statistical group (based on LSD) for the categories with a significant $F$-test; namely, growth at $\mathrm{EC}_{\mathrm{w}} 0, \mathrm{EC}_{\mathrm{w}} 24, \mathrm{EC}_{\mathrm{w}} 32$, and $\mathrm{EC}_{\mathrm{w}} 40 ; \mathrm{EC}_{\mathrm{w}} 25 \% ; \mathrm{EC}_{\mathrm{w}} 50 \% ; \mathrm{LF} 40$.

${ }^{w}$ Within a column, a $\dagger$ denotes the value is within the top statistical category, based on $\operatorname{LSD}_{(0.05)}$.

Ns, **** Nonsignificant or significant at $P \leq 0.001$.

ranged from $3.9 \mathrm{dS} \cdot \mathrm{m}^{-1}$ for 'Adalayd' to 12.3 $\mathrm{dS} \cdot \mathrm{m}^{-1}$ for 'Salam' among the 32 entries (Table 1). However, no significant difference among the entries was found in threshold $\mathrm{EC}_{\mathrm{w}}$. The threshold $\mathrm{EC}_{\mathrm{w}}$ for bermudagrasses ranged from 6.1 ('Tifway') to $11.6 \mathrm{dS} \cdot \mathrm{m}^{-1}$ ('Tifeagle'). The lack of a significant $F$-test for threshold $\mathrm{EC}_{\mathrm{w}}$ indicated that this parameter was less sensitive as a salinity-ranking criterion than the other criteria.

$E C_{w} 25 \%$ and $E C_{w} 50 \%$. Significant differences among the entries were observed in $\mathrm{EC}_{\mathrm{w}} 25 \%$ and $\mathrm{EC}_{\mathrm{w}} 50 \%(P \leq 0.001)$. The $\mathrm{EC}_{\mathrm{w}}$ indicating $25 \%$ growth reduction ranged from 14 to $38 \mathrm{dS} \cdot \mathrm{m}^{-1}$, and it was greater than $25 \mathrm{dS} \cdot \mathrm{m}^{-1}$ for 22 seashore paspalums ranked in the top statistical group (Table 1). All bermudagrasses except 'Tifsport' were in the top group for this criterion.

Maas (1987) noted that the $\mathrm{EC}_{\mathrm{w}} 50 \%$ of plants at salinity $>21 \mathrm{dS} \cdot \mathrm{m}^{-1}$ would be classified as very salt tolerant. Range of the $\mathrm{EC}_{\mathrm{w}} 50 \%$ was 22 to $43 \mathrm{dS} \cdot \mathrm{m}^{-1}$ and the EC $50 \%$ was $\geq 34$ $\mathrm{dS} \cdot \mathrm{m}^{-1}$ for the 25 grasses ranked in the top statistical group. All bermudagrasses were in this group.

LFO and LF4O. No significant difference was found in LF0 among entries, grown under no salinity stress. Significant grass differences were noted for $\operatorname{LF} 40(P \leq 0.001)$, ranging from $7 \%$ to $41 \%$. Twenty-one seashore paspalums showed LF40 $\leq 12 \%$, which was in the top group. All bermudagrasses showed higher LF40 than 'Adalayd' (25\%), with a range of $33 \%$ ('Tifgreen') to $41 \%$ ('Tifeagle').

Correlations between selection criteria. Correlations between inherent growth at $\mathrm{EC}_{\mathrm{w}} 0$ and growth at $\mathrm{EC}_{\mathrm{w}} 24, \mathrm{EC}_{\mathrm{w}} 32$, and $\mathrm{EC}_{\mathrm{w}} 40$ were positive ( $r=0.42,0.41,0.37$, respectively) (Table 2). Many ecotypes with greater inherent growth also had a significantly greater shoot growth at high salinity. Correlation coefficients between Growth $\mathrm{EC}_{\mathrm{w}} \mathrm{O}$ and other growth parameters, such as Growth $\mathrm{EC}_{\mathrm{w}} 24$, Growth $\mathrm{EC}_{\mathrm{w}} 32$, and Growth $\mathrm{EC}_{\mathrm{w}} 40$, decreased as salinity increased. Salinity stress as determined by LF40 exhibited a high negative correlation with Growth $\mathrm{EC}_{\mathrm{w}} 40(r=-0.68)$. Threshold $\mathrm{EC}_{\mathrm{w}}$ was significantly, but weakly, correlated to other parameters.

\section{Discussion}

Nine shoot growth parameters were evaluated to determine the magnitude of diversity in salinity tolerance among grasses and as potential criteria to rank grasses for salinity tolerance. Differences among the 32 entries were demonstrated for all parameters except threshold $\mathrm{EC}_{\mathrm{w}}$ and LF0 (Table 1).

Since recreational turfgrasses are subjected to wear and must possess adequate growth rate to recover, high inherent growth rate at $\mathrm{EC}_{\mathrm{w}} 0$ coupled with greater growth ability at high salinity would be advantageous for effective management on salt-affected sites. Thus, high inherent growth rate (growth at $\mathrm{EC}_{\mathrm{w}} 0$ ) should be considered as an important component when breeders are selecting ecotypes to assess for salinity tolerance that will be used on recreational sites so that the grass can tolerate wear plus salinity stresses.

Growth at $\mathrm{EC}_{\mathrm{w}} 0$ was positively correlated to growth at $\mathrm{EC}_{\mathrm{w}} 24, \mathrm{EC}_{\mathrm{w}} 32$, and $\mathrm{EC}_{\mathrm{w}} 40(r$ $=0.42,0.41$, and 0.37, respectively) (Table 2). Among the 11 seashore paspalums in the highest growth group at $\mathrm{EC}_{\mathrm{w}} 0$, five remained in the highest $\mathrm{EC}_{\mathrm{w}} 40$ growth group (Table 1). Marcum and Murdoch (1994) reported that two of three grasses with highest salinity tolerance (a seashore paspalum, Hawaii selection; and a st. augustinegrass, Stenotaphrum secundatum Walt. Kuntze, Hawaii selection) also had the highest inherent growth rates among the six grasses evaluated. However, the third highly salt tolerant grass [a Manilagrass, Zoysia matrella (L.) Merr.] had the lowest inherent 
growth of all six grasses. As noted by these results, high inherent growth does not mean high salinity tolerance, but adequate growth and potential recovery from injury or excess traffic at high salinity might be achieved by using the turfgrass with potentially high inherent growth.

Since halophytes exhibit enhanced growth as salinity increases from $\mathrm{EC}_{\mathrm{w}} 0$ to moderate to moderately high salinity, correlations of growth at $\mathrm{EC}_{\mathrm{w}} 24$ vs. $\mathrm{EC}_{\mathrm{w}} 32(r=0.91)$ and vs. $\mathrm{EC}_{\mathrm{w}} 40$ $(r=0.88)$ improved substantially over those related to $\mathrm{EC}_{w} 0$ (Table 2). Among the nine seashore paspalums in the top growth category at $\mathrm{EC}_{\mathrm{w}} 24$, five were also in the highest group at $\mathrm{EC}_{\mathrm{w}} 40$ (Table 1). Thus, absolute growth at $\mathrm{EC}_{\mathrm{w}} 24$ provided a better indication for maintaining high growth under very high salinity (i.e., $\mathrm{EC}_{\mathrm{w}} 40$ ) than did growth at $\mathrm{EC}_{\mathrm{w}} 0$.

High absolute growth at $\mathrm{EC}_{\mathrm{w}} 40$ should be an important indicator of a high degree of salinity tolerance. To maintain shoot production at $\mathrm{EC}_{\mathrm{w}} 40$ requires physiologically active leaves in terms of photosynthesis and other biochemical processes. A salinity level $\mathrm{EC}_{\mathrm{w}} 40$ results in growth constraint for most halophytes, so seashore paspalums exhibiting higher shoot yield at this salinity seemed to have adaptation mechanisms for superior salinity tolerance. These mechanisms may include the counteraction of osmotic constraints through water channels (aquaporins), synthesis of compatible solutes (Bohnert and Shen, 1999; Lee, 2000; Marcum, 1999), increased nutrient supply (Duncan and Baligar, 1990; Lee, 2000; Winicov and Seemann, 1990), and/orimproved membrane function (Kupier, 1984; Perez-Prat et al., 1992).

Although salt tolerance evaluation criteria based on growth parameters such as shoot dry weight are time consuming and costly, they have been recognized as the most accurate method if the evaluation parameters (total shoot growth for turfgrasses, yield for agronomic crops) are directly related to economically important uses of the plant (Noble and Rogers, 1992). As a direct indication of a high degree of salinity tolerance, shoot yield at $\mathrm{EC}_{\mathrm{w}} 40$ has a good correlation with LF40 $(r=-0.68)$ (Tables $1,2)$. Both high growth rate and good green color at high salinity are important attributes for survival of a salt-tolerant turfgrass.

Those grasses with high leaf firing at $\mathrm{EC}_{\mathrm{w}} 40$ also had low $\mathrm{EC}_{\mathrm{w}} 40$ growth rates, as would be expected. However, some grasses with minimal leaf firing at $\mathrm{EC}_{\mathrm{w}} 40$ exhibited a low $\mathrm{EC}_{\mathrm{w}} 40$ growth rate, indicating that other factors beyond tissue chlorosis or desiccation limited shoot growth in such ecotypes. Others have suggested leaf firing as a screening criterion for salinity tolerance under very high salinity (Lee et al., 1994; Marcum, 1999; Qian et al., 2000). These results indicated that LF data are appropriate and useful when combined with growth data at a given salinity level.

Salt-tolerant turfgrasses in this study exhibited $\geq 25$ and $\geq 34 \mathrm{dS} \cdot \mathrm{m}^{-1}$ for $\mathrm{EC}_{\mathrm{w}} 25 \%$ and $\mathrm{EC}_{\mathrm{w}} 50 \%$, respectively. Maas (1987) proposed crops having $\mathrm{EC}_{\mathrm{w}} 50 \%>21 \mathrm{dS} \cdot \mathrm{m}^{-1}$ as salt tolerant. While these are important criteria, 22 and 25 grasses out of 32 entries were grouped in

Table 2. Pearson correlation coefficients for inherent growth $\left(\mathrm{GEC}_{\mathrm{w}} 0\right)$, growth at $\mathrm{EC}_{\mathrm{w}} 24, \mathrm{EC}_{\mathrm{w}} 32, \mathrm{EC}_{\mathrm{w}} 40$ $\left(\mathrm{GEC}_{\mathrm{w}} 0, \mathrm{GEC}_{\mathrm{w}} 24, \mathrm{GEC}_{\mathrm{w}} 32\right.$, and $\mathrm{GEC}_{\mathrm{w}} 40$, respectively), threshold $\mathrm{EC}_{\mathrm{w}}, \mathrm{EC}_{\mathrm{w}}$ for $25 \%$ and $50 \%$ growth reduction ( $\mathrm{EC}_{\mathrm{w}} 25 \%$ and $\mathrm{EC}_{\mathrm{w}} 50 \%$, respectively), and percent leaf firing at $\mathrm{EC}_{\mathrm{w}} 40$ (LF 40).

\begin{tabular}{|c|c|c|c|c|c|c|c|}
\hline Parameter & $\mathrm{GEC}_{\mathrm{w}} 24$ & $\mathrm{GEC}_{\mathrm{w}} 32$ & $\mathrm{GEC}_{\mathrm{w}} 40$ & Threshold $\mathrm{EC}_{\mathrm{w}}$ & $\mathrm{EC}_{\mathrm{w}} 25 \%$ & $\mathrm{EC}_{\mathrm{w}} 50 \%$ & LF40 \\
\hline$\overline{\mathrm{GEC}_{\mathrm{w}} \mathrm{O}}$ & $0.42^{* * * *}$ & $0.41^{* * * * *}$ & $0.37^{* * * *}$ & $-0.25^{* *}$ & $-0.15^{\mathrm{NS}}$ & $-0.20^{\mathrm{NS}}$ & $0.11^{\mathrm{NS}}$ \\
\hline $\mathrm{GEC}_{\mathrm{w}} 24$ & --- & $0.91^{* * * *}$ & $0.88^{* * * *}$ & $0.23^{*}$ & $0.46^{* * *}$ & $0.52^{* * *}$ & $-0.62^{* * *}$ \\
\hline $\mathrm{GEC}_{\mathrm{w}} 32$ & --- & --- & $0.91^{* * * *}$ & $0.22^{*}$ & $0.44^{* * * *}$ & $0.50^{* * * *}$ & $-0.63^{* * *}$ \\
\hline $\mathrm{GEC}_{\mathrm{w}} 40$ & --- & --- & --- & $0.25^{*}$ & $0.44^{* * * *}$ & $0.57^{* * * *}$ & $-0.68^{* * *}$ \\
\hline Threshold $\mathrm{EC}_{\mathrm{w}}$ & --- & --- & --- & --- & $0.42^{* * * *}$ & $0.50^{* * * *}$ & $-0.34^{* * *}$ \\
\hline $\mathrm{EC}_{\mathrm{w}} 25 \%$ & --- & --- & --- & --- & --- & $0.81^{* * * *}$ & $-0.45^{* * *}$ \\
\hline $\mathrm{EC}_{\mathrm{w}} 50 \%$ & --- & --- & --- & --- & --- & --- & $-0.48^{* * * *}$ \\
\hline
\end{tabular}

NS, $, * *, * * *$ Nonsignificant or significant at $P \leq 0.05,0.01$, and 0.001 , respectively.

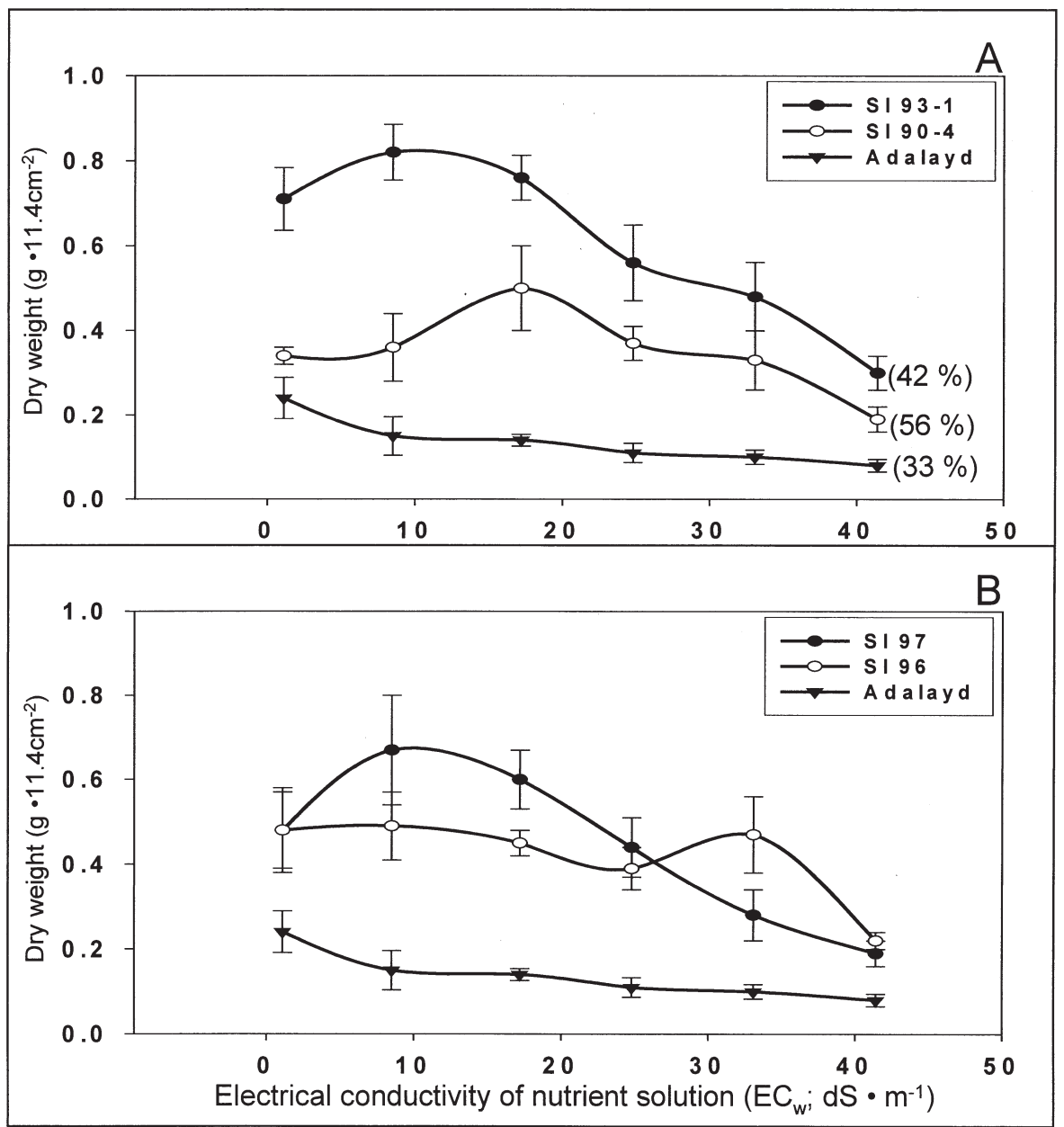

Fig. 1. Comparison of shoot growth responses of three seashore paspalums. Values in parentheses in panel A are percent growth at $\mathrm{EC}_{\mathrm{w}} 40$ compared to control (nonsaline) growth. Bars represent standard errors of the mean $(n=6)$.

the top ranks for the parameters $\mathrm{EC}_{\mathrm{w}} 25 \%$ and $\mathrm{EC}_{\mathrm{w}} 50 \%$, respectively. This is similar for the parameter LF40, where 19 grasses were in the top statistical group. Thus, while the three shoot parameters provided important information for very salt tolerant seashore paspalums, additional selection criteria seem to be required to better define genotypes (ecotypes) having the highest degree of salt tolerance for halophyte breeding programs.

For turfgrasses having growth responses similar to glycophytes (i.e., 'Adalayd', Fig. 1 A and $\mathrm{B}$ ), the threshold $\mathrm{EC}_{\mathrm{w}}$ (or $\mathrm{EC}_{\mathrm{e}}$ ) represents the point where growth starts to decline in response to salinity, which normally occurs at $\mathrm{EC}_{\mathrm{w}} 0$, and the $\mathrm{EC}_{\mathrm{w}} 0$ growth is, therefore, the maximum growth. Most halophytes, however, demonstrate a growth curve similar to that of
SI93-1 (Fig. 1A) where 1) maximum growth is greater than growth at the control, 2) threshold $\mathrm{EC}_{\mathrm{w}}$ is the point of maximum shoot growth, and 3) growth equal to growth at the control may occur at high salinity levels, such as 24 (SI 93-1) and $32 \mathrm{dS} \cdot \mathrm{m}^{-1}$ (SI 90-4) in Fig. 1. However, threshold $\mathrm{EC}_{\mathrm{w}}$ had a nonsignificant $F$-test and a relatively high $\mathrm{Cv}$, indicating that it was less useful among shoot parameters for evaluation of salinity tolerance in the halophytic species even though it is a good criterion for glycophytes, and often used for classification of salt tolerance.

Another aspect of shoot growth under salinity stress is the characteristics of the growth response curve (Fig. 1A). The more tolerant SI 93-1 had 0.71 and $0.30 \mathrm{~g} \mathrm{(100 \%} \mathrm{and} 42 \%$, on a relative basis), while the less tolerant 'Adalayd' 
had 0.24 and $0.08 \mathrm{~g}(100 \%$ and $33 \%)$ at $\mathrm{EC}_{\mathrm{w}} 0$ and at $\mathrm{EC}_{\mathrm{w}} 40$, respectively. SI 93-1 exhibited a halophytic growth response, while 'Adalayd' had a growth response commonly found in glycophytes. These responses illustrated the difficulty in assessing salinity tolerance based on relative growth criteria commonly used for less salt tolerant crops (Maas, 1987). If data were expressed on the relative growth basis (\%) compared to control growth, all seashore paspalums would have $100 \%$ relative growth at $\mathrm{EC}_{\mathrm{w}} 0$. The relative growth for all three ecotypes at $\mathrm{EC}_{\mathrm{w}} 40$, therefore, would be between $33 \%$ to $56 \%$ of the control (i.e., a 1.7 -fold range) (Fig. 1A). In contrast, difference in absolute shoot growth of the three seashore paspalums was 3.8-fold at $\mathrm{EC}_{\mathrm{w}} 40$ on an absolute growth basis. Previous studies based on relative growth have commonly evaluated salinity tolerance among different crops (Maas, 1987; Maas and Hoffman, 1977) or different species (Marcum and Murdoch, 1994). For example, in turfgrass, relative growth $(\%)$ compared to control would be appropriate for two turfgrass species having totally different growth rates, such as St. Augustinegrass vs. Manilagrass, where inherently high yielding St. Augustinegrass and low yielding Manilagrass at control were both found to be salt tolerant (Marcum and Murdoch, 1994). However, the absolute-basis measurement would be desirable in salinity evaluation among intraspecific ecotypes of seashore paspalums or grasses with similar growth habits. Leaf texture and shoot growth ability of bermudagrasses used in this study also were within the range of seashore paspalums (Table 1).

Data shown in Fig. $1 \mathrm{~A}$ and B also illustrate examples of diverse shoot responses at salinity levels of $\mathrm{EC}_{\mathrm{w}} 8$ to $\mathrm{EC}_{\mathrm{w}} 32$, where most crops show the greatest substantial yield reduction (Maas, 1987). Some ecotypes exhibited shoot growth increases with increasing salinity at higher salinity levels near $\mathrm{EC}_{\mathrm{w}} 16$ (SI 90-4, Fig. 1A) or $\mathrm{EC}_{\mathrm{w}} 32$ (SI 96, Fig. 1B). 'Adalayd' growth decreased continuously with increasing salinity. Growth stimulation of these salinity levels may be expected as an adaptation of salinity-tolerant grasses, while sensitive grasses do not exhibit this response. Thus, the nature of growth responses to increasing salinity for halophytic grasses can differ substantially compared to glycophytes. But, commonly accepted criteria for salt tolerance classification have not evolved for halophytes that take into account these growth response differences-which is necessary since traditional glycophyte criteria of threshold $\mathrm{EC}_{\mathrm{w}}$, slope, and relative growth rate are inadequate.

When the objective is to determine shoot performance and salinity tolerance over a wide range of high salinities, ranking across all criteria would provide a good assessment of relative salinity tolerance (Table 1 ). Based on the times in the top (best) statistical group using seven criteria noted in Table 1 that exhibited a significant $F$-test for ecotype differentiation, five seashore paspalums ranked in all seven groups; namely; SI 92, SI 93-1, SI 91, SI 93-2, and SI 89. Within the next grouping, with six out of seven top rankings, was SI 90; followed by those with five out of seven as SI 94-1, 'Sea Isle 1', and 'Taliaferro'. These results reveal that almost all seashore paspalum ecotypes in this study would be ranked as very salt tolerant based on the traditional classification (Maas 1987; Maas and Hoffman, 1977). However, significant diversity among ecotypes for salinity tolerance was apparent within 18 to $41 \mathrm{dS} \cdot \mathrm{m}^{-1}$ ranges. Additional subdivision of salinity tolerance at these high salinities for halophytes, such as seashore paspalum, would be beneficial to breeders and turf managers.

Although bermudagrass has been reported as salt-tolerant, the four bermudagrass cultivars used in this study were relatively less salinity tolerant compared to most seashore paspalum ecotypes. 'Tifgreen', 'Tifeagle', and 'Tifway' ranked in two of the top categories (i.e., $\mathrm{EC}_{\mathrm{w}} 25 \%$ and $\mathrm{EC}_{\mathrm{w}} 50 \%$ ). These responses of bermudagrass are in agreement with earlier studies (Marcum and Murdoch, 1990, 1994) where bermudagrass cultivars responded to increasing salinity levels in a manner intermediate between that of glycophytes and halophytes, demonstrating that these grasses can be effectively managed at moderately low salinity levels $\left(10 \mathrm{dS} \cdot \mathrm{m}^{-1}\right)$ for a long term.

\section{Literature Cited}

Bohnert, H.J., D.E. Nelson, and R.G. Jensen. 1995. Adaptation to environmental stresses. Plant Cell 7:1099-1111

Bohnert, H.J. and B. Shen. 1999. Transformation and compatible solutes. Scientia Hort. 78:237-260.

Carrow, R.N. and R.R. Duncan. 1998. Salt-affected turfgrass sites: Assessment and management. Ann Arbor Press. Chelsea, Mich.

Dudeck, A.E. and C.H. Peacock. 1985. Effects of salinity on seashore paspalum turfgrasses. Agron. J. 77:47-50.

Duncan, R.R. 1996. The environmentally sound turfgrass of the future-seashore paspalum can withstand the test. U.S. Golf Assn. Green Section Record 34:9-11.

Duncan, R.R. 1999a. Environmental compatibility of seashore paspalum for golf courses and other recreational uses. I. Breeding and genetics. Intl. Turfgrass Soc. Res. J. 8(2):1208-1215.

Duncan, R.R. 1999b. Environmental compatibility of seashore paspalum for golf courses and other recreational uses. II. Management protocols. Intl. Turfgrass Soc. Res. J. 8(2):1216-1230.

Duncan, R.R. and V.C. Baligar. 1990. Genetics, breeding, and physiological mechanisms of nutrient uptake and use efficiency: An overview, p. 3-35. In: V.C. Baligar and R.R. Duncan (eds.). Crops as enhancers of nutrient use. Academic Press, San Diego.

Duncan, R.R. and R.N. Carrow. 1999. Turfgrass molecular genetic improvement for abiotic/edaphic stress resistance. Adv. Agron. 67:233-305.

Duncan, R.R. and R. N. Carrow. 2000. Seashore paspalum-The environmental turfgrass. Ann Arbor Press, Chelsea, Mich.

Epstein, E., J.D. Norlyn, D.W. Rush, R.W. Kingsbury, D.B. Kelley, G.A. Cunningham, and A.F. Wrona. 1980. Saline culture of crops: A genetic approach. Science 210:399-404

Greenway, H. and R. Munns. 1980. Mechanisms of salt tolerance in nonhalophytes. Annu. Rev. Plant Physiol. 31:149-190.

Hoagland, D.R. and D.I. Arnon. 1950. The water-culture method for growing plants without soil. Calif. Agr. Expt. Sta. Circ. 347.

Huang, B., R.R. Duncan, and R.N. Carrow. 1997. Drought-resistance mechanisms of seven warmseason turfgrasses under surface soil drying: I. Shoot response. Crop Sci. 37:1858-1863.

Igartua, E. 1995. Choice of selection environment for improving crop yields in saline areas. Theor. Appl. Genet. 91:1016-1021.

Kupier, P.C. 1984. Functioning of plant cell membranes under saline conditions: Membrane lipid composition and ATPases, p. 77-91. In: R.C. Staples and G.H. Toenniessen (eds.). Salinity tolerance in plants: Strategies for crop improvement. Wiley, New York.

Lee, G.J. 2000. Comparative salinity tolerance and salt tolerance mechanisms of seashore paspalum ecotypes. PhD Diss., Dept. of Crop and Soil Sci., Univ. of Georgia, Athens.

Lee, G.J., Y.K. Yoo, and K.S. Kim. 1994. Comparative salt tolerance study in zoysiagrasses: Interspecific comparison among eight zoysiagrasses (Zoysia sp.). J. Korean. Soc. Hort. Sci. 35(2):178-185

Liu, Z., R.L. Jarret, R.R. Duncan, and S. Kresovich. 1994. Genetic relationships and variation among ecotypes of seashore paspalum(Paspalumvaginatum) determined by random amplified polymorphic DNA markers. Genome 37:1011-1017.

Maas, E.V. 1987. Salt tolerance of plants, p. 57-75. In: B.R. Christie (ed.). Handbook of plant science in agriculture. CRS Press, Boca Raton, Fla.

Maas, E.V. and G.J. Hoffmann. 1977. Crop salt tolerance-current assessment. ASCE J. Irr. and Drainage Div. 103(IR2):115-134.

Marcum, K.B. 1999. Salinity tolerance mechanisms of grasses in the subfamily Chloridoideae. Crop Sci. 39:1153-1160

Marcum, K.B. and C.L. Murdoch. 1990. Growth responses, ion relations, and osmotic adaptations of eleven $\mathrm{C}_{4}$ turfgrasses to salinity. Agron. J. 82:892-896.

Marcum, K.B. and C.L. Murdoch. 1994. Salinity tolerance mechanisms of six $\mathrm{C}_{4}$ turfgrasses. J. Amer. Soc. Hort. Sci. 119:779-784.

Marcum, K.B., S.J. Anderson, and M.C. Engelke. 1998. Salt gland and ion secretion: A salinity tolerance mechanism among five zoysiagrass species. Crop Sci. 38:806-810.

Morton, J.F. 1973. Salt-tolerant siltgrass (Paspalum vaginatum Sw.). Proc. Fla. State Hort. Soc. 86:482-490.

Noble, C.L. and M.E. Rogers. 1992. Arguments for the use of physiological criteria for improving the salt tolerance in crops. Plant Soil 146:99-107.

Pasternak,D. 1987. Salt tolerance and crop production-A comprehensive approach. Annu. Rev. Phytopathol. 25:271-291.

Peacock, C.H. and A.E. Dudeck. 1985. Physiological and growth responses of seashore paspalum to salinity. HortScience 20:111-112.

Perez-Prat, E., M.L. Narasimhan, M.L. Binzel, M.A. Botella, Z. Chen, V. Valpuesta, R.A. Bressan, and P.M. Hasegawa. 1992. Induction of a putative $\mathrm{Ca}^{2+}-$ ATPase mRNA in NaCl-adapted cells. Plant Physiol. 100:1471-1478.

Qian, Y.L., M.C. Engelke, and M.J.V. Foster. 2000. Salinity effects on zoysiagrass cultivars and experimental lines. Crop Sci. 40:488-492.

Rengasmy, P. and K.A. Olsson. 1991. Sodicity and soil structure. Austral. J. Soil Res. 29:935-952.

Saranga, Y., A. Cahaner, D. Zamir, A. Marani, and J. Rudich. 1992. Breeding tomatoes for salt tolerance: inheritance of salt tolerance and related traits in interspecific populations. Theoret. Appl. Genet. 84:390-396.

SAS Institute. 1988. Release of 6.03. SAS Inst., Cary, N.C.

Shannon, M.C. 1985. Principles and strategies in breeding for higher salt tolerance. Plant Soil 89:227-241.

Trenholm, L.E., R.R. Duncan, and R.N. Carrow. 1999. Wear tolerance, shoot performance, and spectral reflectance of seashore paspalum and bermudagrass. Crop Sci. 39:1147-1152.

Wilkinson, R.E. and R.R. Duncan. 1994. Seashore paspalum (Paspalum vaginatum Swartz) seminal root response to calcium $\left(45 \mathrm{Ca}^{2+}\right)$ absoption modifiers. J. Plant Nutr. 17:1385-1392.

Winicov, I. and J.R. Seemann. 1990. Expression of genes for photosynthesis and the relationship to salt tolerance of alfafa (Medicago sativa) cells. Plant Cell Physiol. 31:1155-1161. 